\title{
An explanatory study of the use of e-mail investor communication by South African listed companies
}

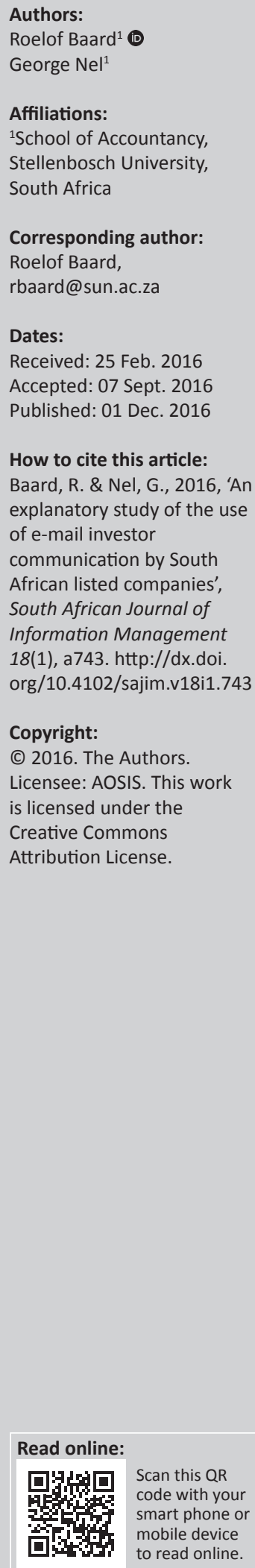

Background: Although research shows that almost all listed companies have corporate websites with dedicated investor relations (IR) sections that enable companies to 'push' information to investors, it was argued that such an asymmetrical approach to communication is insufficient for companies wishing to exercise good IR. The purpose of this study was to test the effectiveness of the Internet to act as a mechanism to achieve more interactive communication between companies and investors.

Objectives: The objectives of the study were to measure the responsiveness, timeliness and relevance of companies' responses to e-mail requests, and to test for the determinants (size, market-to-book ratio, profitability, leverage and liquidity) thereof.

Method: The mystery investor approach and a content analysis were used to study the e-mail handling performance of companies. The associations between company-specific characteristics were statistically tested.

Results: It was found that the e-mail handling performance of companies in this study was poor compared with previous studies. Significant relationships between company size and responsiveness and relevance, and between market-to-book ratio and relevance were reported, as well as between the contact method used to request information and relevance and the use of social media and timeliness.

Conclusion: Specific areas where companies could improve their investor communications were identified. The need for further research was discussed to explain some of the relationships found, as well as those not found, in contrast to what was expected. Future research is warranted to examine the relationship between the e-mail handling performance of companies and information asymmetry and the cost of equity of companies.

\section{Introduction}

The King III ${ }^{1}$ corporate governance code states that transparent and effective communication with stakeholders is essential for building and maintaining their trust and confidence. Stakeholders include, amongst others, investors, employees, suppliers, customers and the community. Investors as stakeholders require information for the evaluation of share investments. Various communication channels are available to companies through which to communicate with investors, such as the annual report, media releases, presentations and the Internet.

Well-known Internet applications today include Twitter, Facebook, YouTube, e-mail and corporate websites. Advantages for companies in using such Internet communication channels include, but are not limited to, cost-effectiveness, flexibility in format, timeliness and ease of accessibility to investors. For investors, on the contrary, these communication channels may be an easy, quick, cheap, complete, reliable and up-to-date source of information that is readily available.

To date, the use of corporate websites as Internet communication channel has by far received the most attention in the literature. Empirically, findings by Venter (2002), Loxton (2003), Nel (2004), Baard and Nel (2006) and Esterhyse and Wingard (2016) have shown that nearly all listed companies in South Africa have a corporate website with a dedicated IR section. Theoretically, a well-developed IR section, as part of a corporate website, will increase company visibility according to the investor recognition hypothesis of Merton (1987). Considerable research has been done on the advantages of using corporate websites as communication channel through an

1.King III (2009) is a corporate governance compliance framework issued by the Institute of Directors in South Africa (IODSA), and compliance thereof is a JSE listing requirement. King IV is currently in progress. 
examination of the relationship between the use thereof and the cost of equity ${ }^{2}$ and information asymmetry. ${ }^{3}$ Froidevaux (2004) and Orens, Aerts and Cormier (2010) found the expected negative association with the cost of equity, and Gajewski and Li (2015) the expected negative association with information asymmetry. Blankespoor, Miller and White (2014) found a negative association between the communication of company-initiated news via Twitter and information asymmetry. Agarwal et al. (2016) found a positive association between IR and company market value.

The use of e-mail as investor communication channel, on the contrary, is largely un-researched in both an international and South African context (except for Hassink, Bollen \& Steggink [2007]). The Hassink et al.'s (2007) sample included the 40 largest companies listed on the Johannesburg Stock Exchange (JSE).

The main purpose of this study was to examine the use of e-mail as investor communication channel by JSE-listed companies. Firstly, through a measurement of how well companies respond to an e-mail request for information by an investor and, secondly, by performing a statistical analysis. How well companies respond was measured with three variables: responsiveness, timeliness and relevance. The purpose of the statistical analysis was to examine whether prior empirical evidence and current theoretical thinking about the determinants of the information communicated to investors are also applicable to the use of e-mail as communication channel. As discussed in the Research Design and Methodology section, this study was conducted in 2014/2015 and comprised of a random sample of 102 JSElisted companies.

According to Mybroadband (2015), the average bandwidth in South Africa increased from 266 kpbs in January 2008 to $3403 \mathrm{kpbs}$ in March 2015. Coupled with the decreased costs in using Internet technologies and the increased accessibility thereof (e.g. through mobile devices) over the last decade, a considerable increase in the use of Internet communication channels by both companies and investors could be reasonably be expected. Studies [including the Hassink et al. (2007) study] that have examined the communication of information to investors usually limit their sample to include only the largest companies based on the criterion - data availability.

\section{Literature review}

Marston (1996:477) defined IR as the link between a company and the financial community in terms of which information for evaluating the company is provided to the financial community. The rise of the Web could be used to distinguish between research studies that explore pre-Web

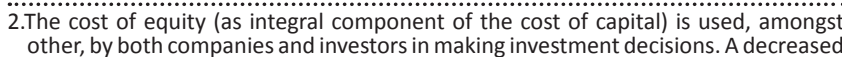
cost of equity equates to an increase in the market value of a company.

3.Information asymmetry refers to the situation where not all investors are equally informed. Economic theory links a decreased information asymmetry to a decreased cost of equity through an increased liquidity. communication channels, for example, printed media, as opposed to post-Web communication channels, for example, corporate websites. According to a Makinson Cowell Report (2009:1.3), the proliferation of information channels has driven users of information closer to source on the companies' own corporate website, unless they are let down by timing.

Marston and Polei (2004:297) argued that, although investors are mainly interested in content, they also want to find this information as quickly and easily as possible. According to Chang et al. (2008:376), the primary objective of IR is not necessarily the provision of information, but rather to improve the flow of information to investors. Gowthorpe (2004:291) distinguished clearly between 'push' and 'pull' information. 'Push' information refers to information determined and supplied by companies to investors. 'Pull' information refers to users specifying the type of information they require. Information supplied by companies via Webbased communication channels could therefore be classified as 'push' information. Although Web-based communication channels could be used by companies to enhance IR, not all Web-based communication channels will benefit investors in the same way. The usefulness thereof could be compromised for three distinct sets of reasons.

The first set of reasons relates to the inherent characteristics of information technology applications. Although additional content, not easily available to all investors, and the use of presentation technologies, such as hyperlinks and alternative digital formats, are by default perceived positively, a number of studies suggest this is not true in all circumstances, for example, information overload (Lybaert 2002:199) and risks associated with hyperlinks (DeStefano \& LeFevre 2007:1616; Dull, Graham \& Baldwin 2003:185).

The second set of reasons relates to the variability of information. Cross-sectional variations in the communication of information and how the information is communicated to investors are well documented (Chang et al. 2008:384; Chatterjee \& Hawkes 2008:50; Debreceny, Gray \& Rahman 2002:383; Froidevaux 2004:77; Lybaert 2002:203; Matherly \& Burton 2005:2; Orens et al. 2010:1084).

The third set of reasons relates to the variety of investors. Given the accessibility of the Web, information pushed to investors by companies will be accessed by investors who will range from the inexperienced ad hoc investor to the more experienced retail investor to the professional institutional investor and analyst. These investors will have different information needs, and corporate websites, for example, may not be able to entirely satisfy the information needs of all investors.

Information pushed to investors, also referred to as asymmetrical communication (Hassink et al. 2007:146), alone will therefore not satisfy the information needs of all investors. The majority of research to date has focused on the 'push' of information to investors. The extant literature could 
further be categorised as descriptive studies, association studies or economic consequence studies.

Descriptive studies describe the use of Web-based communication channels by companies (e.g. measurement of information disclosed via corporate websites using content analysis) compared with association studies, which explore the determinants of Web-based communication. The purpose of economic consequence studies is to establish a link between the use of Web-based communication channels and some proxy for the economic relevance or not thereof, for example, cost of equity (Orens et al. 2010), information asymmetry (Gajewski \& Li 2015) and market value (Agarwal et al. 2016). Following the objectives set (as discussed in the next section), this study could be categorised as both a descriptive and an association study.

\section{Problem statement, purpose and objectives of the study}

The Investor Relations Society (IRS) has published best practice corporate website guidelines that will help companies communicate more effectively with investors and other stakeholders (IRS 2013). One best practice listed by the IRS (2013) is that companies should provide contact details (including an e-mail address) of the IR officer or team responsible for shareholder communication.

Research has shown that almost all corporate websites provide some sort of contact details that investors could use to contact the company to request additional information (Celik, Ecer \& Karabacak 2006; Chang et al. 2008; Chatterjee \& Hawkes 2008; Davey \& Homkajohn 2004; Froidevaux 2004; Khan 2006; Lybaert 2002; Marston \& Polei 2004; Pirchegger \& Wagenhofer 1999).

Given the documented cross-sectional variation in the amount of information companies disclose via corporate websites (as discussed in the Literature Review section), a similar cross-sectional variation is expected in the contact details provided to investors. Some companies will provide only a telephone number or a form that investors can complete to request information, whereas others will provide an e-mail address. It is further expected that some companies will provide only a general e-mail address, for example, companyx@co.za,whereas others may provide a dedicated contact person responsible for investor queries, for example, johnx.companyx@co.za.

The provision of contact details creates the opportunity for both the company and the investor to engage in symmetrical communication as opposed to, for example, corporate websites on which information is only pushed to investors, that is, asymmetrical communication. Although a certain expectation is created by providing contact details, the usefulness thereof will depend on whether companies respond to e-mail queries received. If companies respond, the usefulness of their replies will further depend on the timeliness and relevance of responses. We do not know whether, and with what commitment, companies listed on the JSE will respond to e-mail queries received from an investor who is not known to them. This is the main problem that this study will address.

The purpose of this study therefore is to answer the research questions that follow. Firstly, do companies respond to e-mail queries and, if they respond, how timely and how relevant are their responses? Secondly, what is the impact of companyspecific characteristics on the effectiveness with which companies handle these e-mail queries? To answer these research questions, the following objectives were set for the study:

- To measure the responsiveness of companies to e-mail queries received.

- To measure the timeliness and relevance of responses.

- To test for the determinants of companies' responsiveness, as well as the timeliness and relevance of these responses.

\section{Research design and methodology Measurement of responsiveness, timeliness and relevance}

The initial sample consisted of a random selection of 102 companies listed on the main board of the JSE. This sample represents approximately $33 \%$ of JSE-listed companies. It was assumed that the sample size was sufficiently large to make inferences about the population. This study was limited to listed companies, given the specific information needs necessary to conduct this study successfully. To answer the research questions, a mystery investor approach was followed by sending an e-mail or completing a web enquiry form in 2014/2015. This approach simulates the symmetrical communication via e-mail of the private investor requesting information from a company and was first used by Hassink et al. (2007).

E-mail addresses were obtained by searching on the corporate websites of each of the respective companies. The IR section of the corporate website was searched first for an e-mail address or web enquiry form to complete. If no e-mail address was found, the rest of the corporate website was searched. If an e-mail address could not be found in the IR section, an e-mail address was generally found under the 'Contact Us' section of the corporate website.

Following an initial screening of corporate websites, the sample was reduced to 94 companies, excluding both companies that did not have a corporate website and companies for which no contact details (either an e-mail address or web enquiry form) could be found on the website.

The remaining 94 companies allowed the potential investor to communicate with them by either sending an e-mail or completing a web enquiry form. Some companies provided a dedicated IR e-mail address, whereas others only provided a general e-mail address. In a similar vein, some companies provided an investor with a tailored web enquiry form, 
whereas others provided only a general web enquiry form for all types of company-related queries.

A Gmail address was set up for the mystery investor. The name of the mystery investor was Gary Anderson and the e-mail address used was andersongary900@gmail.com. It was stated in the e-mail that the person was a potential investor requiring certain information. All communication (except for what had to be completed on a web enquiry form on the corporate website) was sent from this e-mail address. The e-mails were sent at the same time. Another two companies were subsequently removed from the sample, as one company's e-mail facility was blocked and another's e-mail returned a message that it was full, reducing the final sample to 92 companies. Table 1 shows a reconciliation of the initial sample of 102 companies with the final sample of 92 companies.

Table 2 provides a summary of the contact method used to communicate with the 92 companies.

An information request was prepared containing three detailed questions. The questions in the e-mail focused on dividend policy, current debt ratings and the use of various forms of social media. The purpose of the questions was to ask for information that was not necessarily available in the annual report or on their corporate websites and which they could just refer to.

Following research by Hassink et al. (2007), three variables were used to describe the e-mail-handling performance of the companies: responsiveness, timeliness and relevance. Responsiveness was measured either as 0 or 1,0 being that the e-mail was not answered and 1 being that the e-mail was answered. Timeliness was measured in hours from when the e-mail was sent until when the e-mail response was received. If companies did not respond within 2 weeks, a reminder containing the original questions was sent.

For the purposes of this study, a distinction was made between the total response time (including responses after the reminder) and the response time before the reminder was sent (within 2 weeks of the e-mail being sent). This was done to ensure that a couple of companies taking very long to respond did not skew the timeliness analysis.

TABLE 1: Summary of the original and reduced sample size.

\begin{tabular}{lc}
\hline Detail & Number \\
\hline Original sample & 102 \\
No website & 3 \\
No contact details provided & 5 \\
Mailbox full message & 1 \\
E-mail blocked message & 1 \\
Reduced sample & 92 \\
\hline
\end{tabular}

TABLE 2: Summary of contact method used.

\begin{tabular}{lcc}
\hline Contact method & Number & $\mathbf{\%}$ \\
\hline E-mail sent to general e-mail (web form included) & 57 & 62 \\
E-mail sent to IR department e-mail (web form included) & 35 & 38 \\
\hline
\end{tabular}

To test for the relevance of the e-mail responses, content analysis was used to study the answers and thus determine whether the questions were answered adequately. The score for relevance ranges from 8 (all the questions were answered adequately and explained) to 0 (none of the questions was answered adequately).

\section{Determinants of responsiveness, timeliness and relevance}

One of the objectives of this study was to test for the determinants of responsiveness, as well as the timeliness and relevance of responses as dependent variables. The characteristics of companies that were covered in association studies to date include, amongst others, ${ }^{4}$ size, market-to-book ratio, profitability, leverage and liquidity. The theoretical grounds for using these variables will now be discussed briefly. The discussion should be read with the following in mind: The studies discussed below all used information pushed to investors as proxy for information. Although it could easily be argued that information communicated by companies to investors based on their requests (i.e. pulled) could also be seen as 'disclosure', there is an important difference.

Currently, information 'pushed' by JSE-listed companies to investors via the Web (e.g. corporate websites) is voluntary in nature. As such, an important consideration for companies to consider when deciding whether or not to engage in Webbased communication is the cost versus the expected benefits thereof.

One of the advantages of using Web-based communication channels is the relatively low cost and ease with which companies can communicate. Employing a dedicated team of experts to respond to individual e-mail queries may not be viewed as cost-effective. This is an even more relevant concern when an information request is received from an unknown investor. As discussed in the Research Design Methodology section, this study created this exact situation in relation to the companies surveyed.

\section{Company size}

According to Celik et al. (2006:107), size is the variable used the most in the literature to explain disclosure levels. The majority of studies to date show a positive relationship between the size of a company and the amount of information disclosed. According to Marston and Polei (2004:294), the relative production costs of information are lower for larger companies than for smaller ones. Larrán and Giner (2002:65), on the contrary, argued that the cost of preparing and communicating information via the Web is independent of size, but that the benefits arising from more disclosure should be more for larger companies.

Debreceny et al. (2002:377) argued that larger companies have higher information asymmetry between managers and

4.Some studies also test for associations between industry type, systematic risk ownership status, number of listings, financing activities, level of technology used,
analyst following, level of corporate governance and the amount of information analyst follow. 
shareholders and therefore higher agency costs. One way to reduce agency cost is to disclose more information. The political cost hypothesis is offered as another possible reason for a positive relationship between company size and disclosure Debreceny et al. (2002:378). According to this hypothesis, larger companies have a stronger incentive to enhance their corporate reputation and public image, as they are more publicly visible.

In the context of this study, it was expected that larger companies would have better e-mail-handling performance than smaller companies. Former studies used either one or a combination of the following variables as proxy for the size of the company: turnover, number of employees, total assets and market capitalisation. For this study, company size was measured using market capitalisation.

\section{Market-to-book ratio}

According to Orens et al. (2010:1070), the market-to-book ratio is a proxy for future growth opportunities. According to Ohlson (2005), growth prospects and intangibles are intertwined and the difference between market value and book value broadly represents these two variables. Debreceny et al. (2002:380) argued that companies with high market-tobook ratios have specific knowledge that is not effectively and efficiently transferable to investors through traditional accounting disclosures (e.g. annual report). According to Larrán and Giner (2002:66), these companies will have a greater need to disclose information to enable the company to be valued properly.

Such companies therefore have an incentive to 'push' more information to investors via Web-based communication channels. In the context of the objectives of this study, this provides the theoretical backing to expect companies with higher levels of market-to-book ratios to have superior e-mail-handling performance compared to companies with lower market-to-book ratios.

\section{Profitability}

Marston and Polei (2004:294) argued that more profitable companies have the incentive to distinguish themselves from less successful companies by disclosing more information based on signalling theory. According to Larrán and Giner (2002:66), signalling theory suggests that companies with 'good news' will disclose more information and companies with 'bad news' will disclose less information. Nondisclosure of information or, in the context of this study, not responding to the e-mail queries of investors may be perceived as 'bad news' by investors.

It was therefore expected that more profitable companies would have better e-mail-handling performance compared to less successful companies. Profitability was measured using the return on equity percentage.

\section{Leverage and liquidity}

Debreceny et al. (2002:381) postulated that companies with high debt-to-equity ratios may be induced to disclose more information to assure stakeholders, such as investors and debt holders, of the ability of the company to pay its debts. As discussed in the Research Design and Methodology section, companies' e-mail-handling performance was tested specifically in respect of an e-mail query relating to the credit rating of the company.

A positive relationship between leverage and liquidity and the e-mail-handling performance of companies therefore was expected. Leverage was measured using the percentage of debt-to-equity. Liquidity was measured as the ratio between current assets and current liabilities.

Following the extant literature on the determinants of Web IR, and as discussed above, the explanatory power of the following independent variables was tested:

- Company size

- Market-to-book ratio

- Profitability

- Leverage and liquidity

In addition to these variables identified in the literature, the explanatory power of the following variables as measured by the use of the responses received from the companies also was tested:

- Use of social media (e.g. Facebook, Twitter and YouTube)

- Contact method used (refer to Table 2).

\section{Empirical results Descriptive statistics}

Tables 3 and 4 illustrate the descriptive statistics of the dependent and independent variables. The descriptive statistics of the dependent variables (Table 3) are discussed below.

\section{Responsiveness}

Of the 92 companies in the sample, 65 (71\%) replied to the e-mail requesting information. Of the 65 companies that

TABLE 3: Descriptive statistics of the dependent variables.

\begin{tabular}{|c|c|c|c|c|c|c|c|c|c|}
\hline E-mail-handling performance (dependent variables) & $N$ & Mean & Median & SD & Min & Max & Sample & Responded & Response rate \\
\hline Timeliness (in hours) (first e-mail only) & 40 & 50.84 & 4.84 & 79.66 & 0.08 & 311.37 & - & - & - \\
\hline Timeliness (in hours) (first e-mail and reminder) & 65 & 217.59 & 150.50 & 273.45 & 0.08 & 1638.23 & - & - & - \\
\hline Relevance (score) (first e-mail only) & 40 & 4.83 & 6.00 & 2.19 & 0.00 & 8.00 & - & - & - \\
\hline Relevance (score) (first e-mail and reminder) & 65 & 5.03 & 6.00 & 2.05 & 0.00 & 8.00 & - & - & - \\
\hline Relevance (score) (after reminder) & 25 & 5.36 & 6.00 & 1.73 & 1.00 & 8.00 & - & - & - \\
\hline Responsiveness (first e-mail only) & - & - & - & - & - & - & 92 & 40 & $44 \%$ \\
\hline Responsiveness (first e-mail and reminder) & - & - & - & - & - & - & 92 & 65 & $71 \%$ \\
\hline
\end{tabular}


TABLE 4: Descriptive statistics of the independent variables.

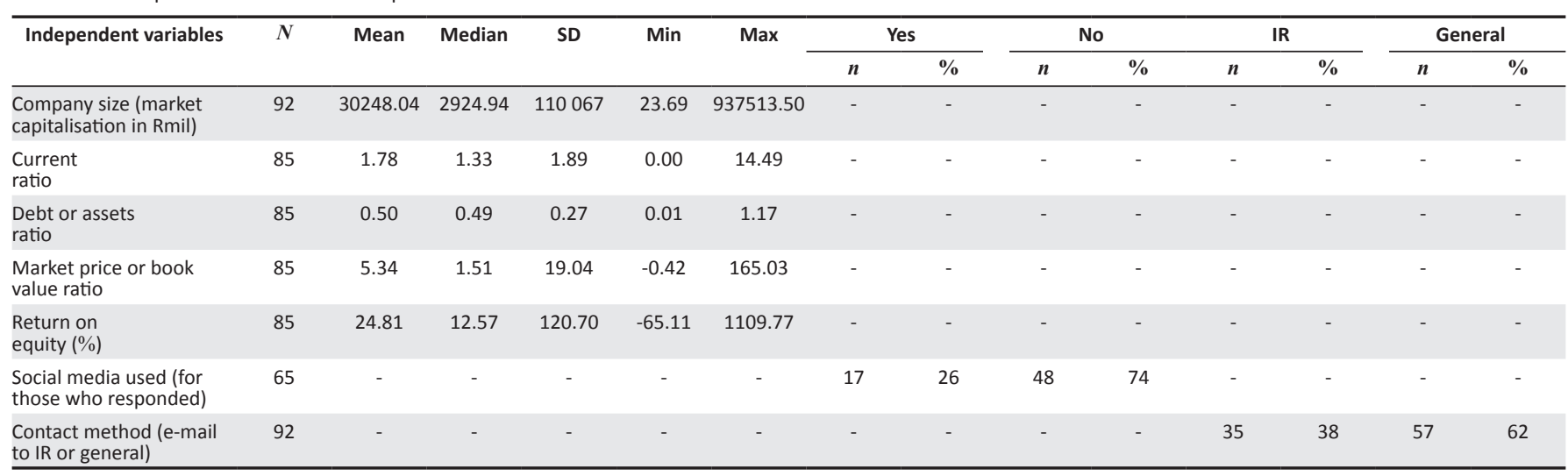

responded, $40(44 \%)$ replied within the first 2 weeks after the e-mail was sent and another 25 (27\%) companies responded after a reminder e-mail was sent. Of the sample, 27 (29\%) companies did not answer the e-mail, even after a reminder was sent. There was no indication that there were any technical difficulties with these e-mail addresses of the companies that did not respond. Considering that the sample of 92 companies was from companies listed on the JSE, the response rates were rather poor. In a similar study conducted by Hassink et al. (2007) on the 40 largest companies listed on the JSE, the response rate was slightly higher, at $76 \%$. They also found the response rate of the 40 largest companies in each of Australia, the UK, the Netherlands, Belgium, France and South Africa to be in the region of $70 \%$. A study conducted by Patel (2012) on 50 listed Indian companies found that websites of Indian companies lack interactivity, as only $20 \%$ of companies facilitate two-way communication between the company and the investors.

\section{Timeliness}

The mean response time within the first 2 weeks (40 companies responded within 2 weeks) was 50.84 hours (2.12 days) and the median was 4.84 hours. One company answered within 5 minutes, whereas another company took as long as 13 days to answer. Of the 40 companies that answered within the first 2 weeks, 27 (68\%) answered within 24 hours and $30(75 \%)$ companies answered within 48 hours ( 2 days). This could be considered a quick response time. Hassink et al. (2007) found similar median response times in their study on the 40 largest companies in South Africa.

The mean response time for all the companies that responded (65 companies), reminder included, was 217.59 hours (9 days) and the median was 150.50 hours (6.27 days). Compared with the response times of companies that answered before the reminder was sent, the mean and the median response times are considerably higher. This is because some companies took very long to answer. One company took a total of 1638.23 hours (68 days) to answer. This can be considered as an outlier, as all the other 64 companies that responded did so within 30 days.

\section{Relevance}

The score for relevance ranged from 8 (all the questions were answered adequately and explained) to 0 (none of the questions was answered adequately or explained). The mean relevance score for the 65 companies that responded was 5.03 $(63 \%)$ out of a possible score of 8 , and the median relevance score was $6(75 \%)$. Only two companies did not answer any of the questions (score 0 ), and three companies answered all of the questions adequately (score 8$)$. There were 38 (58\% that responded) companies that scored a relevance score of 6 (75\%) or higher. In general, companies that responded answered the questions adequately.

The mean relevance score of the 40 companies that responded within the first 2 weeks (before the reminder) was slightly lower, at $4.83(60 \%)$, compared to the overall mean relevance score. The mean relevance score of the 25 companies that responded after the reminder was sent was higher, at 5.36 $(67 \%)$. An analysis of variance ( $F$-test) showed no statistically significant difference $(p>0.10)$ in the mean relevance scores of those companies that answered within the first 2 weeks compared to those companies that responded after the reminder was sent.

\section{Univariate tests}

Tables 5-9 show the univariate tests between the dependent and the independent variables. From the various univariate tests, the following factors were found to be statistically non-significant $(p>0.10)$ in explaining differences in the e-mail-handling performance of companies: current ratio, debt-to-assets ratio and return on equity.

Factors that were found to be significant $(p<0.10)$ in explaining some of the differences in the quality of responses of the companies were company size, contact method, whether companies use social media or not to communicate with investors, and market price-to-book value ratio. These factors will be discussed in more detail in the sections that follow.

\section{Company size}

Univariate tests based on the natural log of market capitalisation were used. The results from the univariate tests 
show that there was a statistically significant relationship between company size and response rates. Companies that are larger respond to e-mails significantly $(p<0.05)$ more than companies that are smaller (Table 5). Although the univariate tests found a positive correlation between company size and relevance scores, the results were nonsignificant $(p>0.05)$. This correlation was only found to be statistically significant at $10 \%(p=0.10)$. Also there was no correlation between company size and timeliness.

Although the majority of studies to date have shown a positive relationship between disclosure and company size, it should be noted that these studies measured the amount of information 'pushed' to investors via corporate websites, in contrast to this study, which focused on the 'pull' of information by investors, that is, the e-mail-handling performance of companies.

\section{Market price-to-book value ratio}

Companies with a higher price-book value ratio showed a positive correlation ( $r=0.23$ ) (Table 6) with the relevance scores of the answered e-mails. This correlation was found to be statistically significant at $10 \%(p<0.10)$. No significant correlation was found between price-book value ratios and response rates or timeliness $(p>0.10)$.

\section{Contact method}

The e-mails were either sent to a person within the IR department, if one was available, or to a general e-mail or contact address, which was generally found under the 'Contact Us' section of the corporate website. It would be expected that the timeliness and relevance of the e-mail responses would be of higher quality if sent to IR department e-mail addresses (Hassink et al. 2007). The reason for this is that there is a dedicated person within the IR department of

TABLE 5: Univariate results of company size.

\begin{tabular}{|c|c|c|c|c|c|c|c|c|}
\hline \multirow{2}{*}{$\begin{array}{l}\text { Variable } \\
\text { Reminder } \\
\text { sent }\end{array}$} & \multirow[t]{2}{*}{$N$} & \multirow[t]{2}{*}{ Mean } & \multicolumn{2}{|c|}{ Responsiveness } & \multicolumn{2}{|c|}{ Timeliness } & \multicolumn{2}{|c|}{ Relevance } \\
\hline & & & & & & & & \\
\hline Yes & 65 & 9.57 & $r$ & $p$ & $r$ & $p$ & $r$ & $p$ \\
\hline No & 27 & 9.12 & - & - & - & - & - & - \\
\hline \multicolumn{9}{|c|}{$\begin{array}{l}\text { Univariate test } \\
\text { (reminder included) }\end{array}$} \\
\hline ANOVA $F$-test & - & - & - & 0.03 & - & - & - & - \\
\hline Spearman & - & - & - & - & 0.00 & 1.00 & 0.21 & 0.10 \\
\hline
\end{tabular}

TABLE 6: Univariate results of market-book value ratio.

\begin{tabular}{lcccccc}
\hline Univariate test (reminder included) & \multicolumn{2}{c}{ Timeliness } & & \multicolumn{2}{c}{ Relevance } \\
\cline { 2 - 3 } \cline { 5 - 6 } & $\boldsymbol{r}$ & $\boldsymbol{p}$ & & $\boldsymbol{r}$ & $\boldsymbol{p}$ \\
\hline Spearman & -0.04 & 0.75 & & 0.23 & 0.08 \\
\hline
\end{tabular}

the company who is specifically employed to deal with investor-related queries. A person servicing the general e-mail queries might not understand the question or know to whom it should be forwarded.

The use of a specific IR e-mail address did not significantly $(p>0.10)$ affect the quality of the e-mail responses in terms of responsiveness or timeliness (Table 7). Companies with a specific IR e-mail address on average responded better $(77 \%$ response rate) compared to companies that were only using a general contact e-mail address (67\% response rate). However, it was interesting to note that e-mail queries sent to the general e-mail address were answered more timely (189.29 hours) than those e-mails sent to the IR department (257.42 hours). None of these differences were significant.

The use of a specific IR e-mail address, however, did have a significant effect on the relevance scores of the e-mail responses. The mean relevance score of responses that were sent to an IR e-mail address was 5.59, and it was 4.63 for e-mails sent to a general e-mail address. This difference was statistically significant $(p<0.10)$. Because the relevance scores were not a normal distribution, a non-parametric statistical technique, called bootstrap, was used as a univariate test. This technique also confirmed the significant difference $(p<0.05)$ in the mean relevance scores. The results show that e-mails sent to IR departments tend to be responded more, answered more adequately, but take longer to be answered compared to e-mails sent to a general contact address.

It was also noted that the companies tended to answer questions more adequately after a reminder was sent. The mean relevance score of responses that were received after a reminder was sent was 5.36, compared to 4.82 for answers received within the first 2 weeks, before the reminder was sent (Table 8). However, this difference was statistically nonsignificant $(p>0.05)$.

\section{Social media}

One of the questions asked in the e-mail sent to companies was whether they made use of social media (Twitter, Facebook and YouTube) to communicate with investors.

TABLE 8: Univariate results of reminder sent.

\begin{tabular}{lcccc}
\hline Reminder sent & $N$ & \multicolumn{3}{c}{ Relevance } \\
\cline { 3 - 5 } & & Mean & Median & $\begin{array}{c}\text { Univariate test } \\
\text { (before and after reminder) }\end{array}$ \\
\cline { 3 - 5 } & & & & ANOVA $\boldsymbol{F}$-test \\
\hline No & 40 & 5.36 & 6.00 & - \\
Yes & 25 & 4.82 & 6.00 & 0.31 \\
\hline$p$ & - & - & - & \\
\hline
\end{tabular}

TABLE 7: Univariate results of contact method.

\begin{tabular}{|c|c|c|c|c|c|c|c|c|c|c|c|c|}
\hline \multirow[t]{3}{*}{ Variable } & \multirow[t]{3}{*}{$N$} & \multicolumn{3}{|c|}{ Responsiveness } & \multicolumn{4}{|c|}{ Timeliness } & \multicolumn{4}{|c|}{ Relevance } \\
\hline & & \multicolumn{2}{|c|}{ Response rate } & \multirow{2}{*}{$\begin{array}{c}\begin{array}{c}\text { Univariate test } \\
\text { (reminder included) }\end{array} \\
\text { Chi-square }\end{array}$} & \multirow[t]{2}{*}{ Mean } & \multirow[t]{2}{*}{ Median } & \multicolumn{2}{|c|}{$\begin{array}{l}\text { Univariate test (reminder } \\
\text { included) }\end{array}$} & \multirow[t]{2}{*}{ Mean } & \multirow[t]{2}{*}{ Median } & \multicolumn{2}{|c|}{$\begin{array}{c}\text { Univariate test } \\
\text { (reminder included) }\end{array}$} \\
\hline & & $n$ & $\%$ & & & & ANOVA $F$-test & Bootstrap & & & ANOVA F-test & Bootstrap \\
\hline IR & 35 & 27 & 77 & - & 257.42 & 171.47 & - & - & 5.59 & 6.00 & - & - \\
\hline General & 57 & 38 & 67 & - & 189.29 & 29.45 & - & - & 4.63 & 6.00 & - & - \\
\hline$p$ & - & - & - & 0.28 & - & - & 0.33 & 0.15 & - & - & 0.06 & 0.02 \\
\hline
\end{tabular}


TABLE 9: Univariate results of social media.

\begin{tabular}{|c|c|c|c|c|c|c|c|}
\hline \multirow[t]{3}{*}{ Social media } & \multirow[t]{3}{*}{$N$} & \multicolumn{3}{|c|}{ Timeliness } & \multicolumn{3}{|c|}{ Relevance } \\
\hline & & \multirow[t]{2}{*}{ Mean } & \multicolumn{2}{|c|}{ Univariate test (reminder included) } & \multirow[t]{2}{*}{ Mean } & \multicolumn{2}{|c|}{ Univariate test (reminder included) } \\
\hline & & & ANOVA F-test & Bootstrap & & ANOVA F-test & Bootstrap \\
\hline Yes & 17 & 96.53 & - & - & 5.29 & - & - \\
\hline No & 48 & 164.01 & - & - & 4.94 & - & - \\
\hline$p$ & - & - & 0.08 & 0.03 & - & 0.54 & 0.24 \\
\hline
\end{tabular}

It was expected that companies with a higher social media presence would have a higher quality of e-mail-handling performance in relation to requests for information from potential investors. Univariate tests to test for the significance of social media were only done on companies that responded to the e-mail sent (65 companies). Of the 65 companies that responded, 17 (26\%) indicated they made use of social media, whereas 48 (74\%) indicated they had no social media presence (Table 9).

Companies with a social media presence tend to have higher quality of e-mail-handling performance than companies that have no social media presence. Companies with social media respond more timely (96.53 hours compared to 164.01 hours) and on average also give more relevant answers (5.29 compared to 4.94). The difference in the relevance scores was found to be non-significant $(p>0.10)$, but the difference in timeliness was found to be significant $(p<0.10)$.

\section{Conclusion}

Notwithstanding the advantages of using corporate websites as communication channel, it was argued in this study that, given the limitations of using a corporate website only to 'push' information to investors, companies potentially could enhance IR through engagement by way of a more symmetrical approach, where investors are endorsed to request information from a company. The main purpose of this study was to investigate the quality of symmetrical company-investor communication in a South African context. As proxy for the quality thereof, the e-mail-handling performance, as measured by the responsiveness, timeliness and relevance of a company's response to an investor-related information request, was measured.

Only $65(71 \%)$ of companies to which the information request was successfully delivered responded to the request received. Considering the 10 companies removed from the initial sample (refer to Table 1), it was not possible to obtain information from $37(36 \%)$ of the 102 companies. On the issue of timeliness, companies could be categorised into two extremely diverse groups. Group one consisted of 30 companies that responded within 48 hours, compared to the remaining 35 companies, categorised into group two, from which 25 companies only responded after the reminder was sent after 2 weeks. Relevance was measured using an eightpoint scale. Companies that responded adequately on average supplied $63 \%$ of the information as requested.

The secondary purpose of this study was to test the statistical significance of variables to explain companies' e-mail-handling performance, some as used in prior studies (e.g. company size, market price-to-book, profitability, leverage and liquidity), and others as a result of measurements made in this study (e.g. contact method and use of social media). Of the variables tested, only company size, market price-to-book value, contact method and social media were found to be statistically significant.

Larger companies statistically have higher response rates and more relevant answers than smaller companies. The market price-to-book value ratio was also found to be a statistically significant explanatory variable, although only at the $10 \%$ level, to explain the relevance of answers.

As expected, information requests submitted via a dedicated IR e-mail address or web query form were statistically associated with more relevant answers compared to requests submitted via a general e-mail or web query form. Regarding the use of social media as additional and/or alternative communication channel, a statistically significant relationship was found between the use of social media and timeliness.

No significant relationships were found between profitability, leverage and liquidity, and the e-mail-handling performance of companies. Studies to date show conflicting results between these variables and the amount of information disclosed to investors via corporate websites.

Given the outcomes of this study, further research is necessary to understand the underlying reasons for the statistically significant relationships found, as well as for those not found, some as a surprise in contrast to what was expected. First was the unexpected, although not statistically significant, positive relationship between timeliness and information requests submitted via a general e-mail address or web query form. Second was the absence of any relationship between company size and timeliness. Last was the absence of any difference in the mean relevance scores of companies that responded before and after the 2-week reminder.

A further limitation of this study is the absence of readily available benchmarks against which to assess the e-mail handling performance of companies as measured in this study (except for the Hassink et al. 2007 study). It should be emphasised that besides using the corporate website or e-mail functionality to communicate with investors, companies have a wide variety of communication channels available to communicate with investors, for example: the integrated annual report, investor presentations, Twitter, YouTube and Facebook. Further, although the publication of an integrated annual report is compulsory for JSE-listed 
companies, the decision to use any one of the Internet-related communication channels as mentioned or discussed in this study (i.e. corporate websites, e-mail, Twitter, Facebook and YouTube) is voluntary in the South African context. Two further possible reasons could be offered as explanation for the perceived mediocre e-mail handling performance as measured in this study.

The first reason relates to the voluntary nature and the availability of alternative communication channels. The second reason, which also warrant further research, is based on a cost-benefit trade off. Companies will only optimally use voluntary communication if the perceived benefits outweighs the estimated costs thereof.

Although considerable research has been done on the advantages of using corporate websites as communication channel, to the best knowledge of the writers no research has been published that has examined the relationship between the quality of companies' e-mail handling performance and information asymmetry, the cost of equity and the market value of a company.

Research opportunities exist to further investigate the relationship between the quality of information 'pushed' to investors via corporate websites and the e-mail-handling performance of companies, the influence of ownership structure on the above relationships found and not found, and the use and perception of various investor types (e.g. private compared to institutional) of the e-mail-handling performance of companies as reported in this study in comparison with what was expected by them.

\section{Acknowledgements Competing interests}

The authors declare that they have no financial or personal relationships which may have inappropriately influenced them in writing this article.

\section{Authors' contributions}

R.B. and G.N. wrote the manuscript. R.B. gathered the data and the statistical analysis was performed by G.N.

\section{References}

Agarwal, V., Taffler, R.J., Bellotti, X. \& Nash, E.A., 2016, 'Investor relations, information asymmetry and market value', Accounting and Business Research 46(1), 31-50. http://dx.doi.org/10.1080/00014788.2015.1025254

Blankespoor, E., Miller, G.S. \& White, H.D., 2014, 'The role of dissemination in market liquidity: Evidence from firms' use of Twitter', The Accounting Review 89(1), 79-112. http://dx.doi.org/10.2308/accr-50576

Celik, O., Ecer, A. \& Karabacak, H., 2006, 'Impact of firm specific characteristics on the web based business reporting: Evidence from the companies listed in Turkey', Problems and Perspectives in Management 4(3), 100-133.

Chang, M., D’Anna, G., Watson, I. \& Wee, M., 2008, 'Does disclosure quality via investor relations affect information asymmetry?' Australian Journal of Management 33(2), 375-390. http://dx.doi.org/10.1177/031289620803300208
Chatterjee, B. \& Hawkes, L., 2008, 'Does internet reporting improve the accessibility of financial information in a global world?', Australasian Accounting Business and Finance Journal 2(4), 33-56.

Davey, H. \& Homkajohn, K., 2004, 'Corporate internet reporting: An Asian example', Problems and Perspectives in Management 2, 211-227.

Debreceny, R., Gray, G.L. \& Rahman, A., 2002, 'The determinants of Internet financial reporting', Journal of Accounting and Public Policy 21(4-5), 371-394. http://dx. doi.org/10.1016/S0278-4254(02)00067-4

DeStefano, D. \& LeFevre, J., 2007, 'Cognitive load in hypertext reading: A review', Computers in Human Behavior 23, 1616-1641. http://dx.doi.org/10.1016/j. chb.2005.08.012

Dull, R.B., Graham, A.W. \& Baldwin, A.A., 2003, 'Web-based financial statements: Hypertext links to footnotes and their effect on decisions', International Journal of Accounting Information Systems 4, 185-203. http://dx.doi.org/10.1016/S1467Accounting Inform

Esterhyse, L. \& Wingard, C., 2016, 'An exploration of the online investor relations (IR) practices of companies listed on the Johannesburg Stock Exchange (JSE)', South African Journal of Economic and Management Sciences 19(2), 215-231. http:// dx.doi.org/10.17159/2222-3436/2016/v19n2a4

Froidevaux, E.A., 2004, 'Investor relations, internet disclosure and the cost of equity capital', PhD thesis, University of Fribourg, Switzerland, viewed 24 October 2012 from http://ethesis.unifr.ch/theses/downloads.php?file=FroidevauxE.pdf

Gajewski, J. \& Li, L., 2015, 'Can Internet-based disclosure reduce information asymmetry?', Advances in Accounting, Incorporating Advances in International Accounting 31(1), 115-124.

Gowthorpe, C., 2004, 'Asymmetrical dialogue? Corporate financial reporting via the Internet', Corporate Communications: An International Journal 9(4), 283-293. http://dx.doi.org/10.1108/13563280410564020

Hassink, H., Bollen, L. \& Steggink, M., 2007, 'Symmetrical versus asymmetrical companyinvestor communications via the internet', Corporate Communications: An InternationalJournal12(2),145-160.http://dx.doi.org/10.1108/13563280710744829

IRS (Investor Relations Society), 2013, Best practice guidelines for websites, viewed 11 July 2013, from http://www.irs.org.uk/resources/best-practice-guidelines

Khan, T., 2006, Financial reporting disclosures on the internet: An international perspective, Faculty of Business and Law School of Accounting, Victoria University, Australia.

King III., 2009, Institute of Directors in South Africa, viewed 01 September 2016, from http://www.iodsa.co.za

Larrán, M. \& Giner, B., 2002, 'The use of the Internet for corporate reporting by Spanish companies', The International Journal of Digital Accounting Research 2(1), 53-82. http://dx.doi.org/10.4192/1577-8517-v2_3

Loxton, L., 2003, 'Beleggersverhoudinge op die Internet:'n Ondersoek in Suid-Afrika', Meditari 11(1), 80-94.

Lybaert, N., 2002, 'Online financial reporting: An analysis of the Dutch listed firms', The International Journal of Digital Accounting Research 2, 195-234.

Makinson Cowell Report, 2009, Corporate websites, viewed 22 January 2013, from http://www1.investis.com/ /media/Files/I/Investis-V2/pdf/publications/ corporate-websites-july-2009-v2.pdf

Marston, C., 1996, 'The organisation of the investor relations function by large UK quoted companies', Omega 24(4), 477-488. http://dx.doi.org/10.1016/03050483(96)00015-1

Marston, C. \& Polei, A., 2004, 'Corporate reporting on the Internet by German companies', International Journal of Accounting Information Systems 5(3), 285311. http://dx.doi.org/10.1016/j.accinf.2004.02.009

Matherly, C.M. \& Burton, H.A., 2005, 'An analysis of corporate website disclosures', Management Accounting Quarterly Winter 6(2), 26-33.

Merton, R.C., 1987, 'A simple model of capital market equilibrium with incomplete information', The Journal of Finance 42(3), 483-510. http://dx.doi. org/10.1111/j.1540-6261.1987.tb04565.x

Mybroadband, 2015, South African broadband speeds: 2008 to 2015, viewed 01 September 2016, from http://mybroadband.co.za/news/broadband/122398 south-african-broadband-speeds-2008-to-2015.htm

Nel, G.F., 2004, 'Future of financial reporting on the Internet', South African Journal of Information Management, 6(2), June, viewed 23 February 2006, from http://www. sajim.co.za/index.php/SAJIM/article/viewFile/387/374

Nel, G. \& Baard, R., 2006, 'Using corporate web sites in Africa to market to investors', South African Journal of Information Management, 8(3), September, viewed 23 July 2012, from http://www.sajim.co.za/index.php/SAJIM/article/viewFile/228/223

Ohlson, J.A., 2005, 'On accounting-based valuation formulae', Review of Accounting Studies 10(23), 323-347. http://dx.doi.org/10.1007/s11142-005-1534-4

Orens, R., Aerts, W. \& Cormier, D., 2010, 'Web-based non-financial disclosure and cost of finance', Journal of Business Finance and Accounting 37(9), 1057-1093. http:// dx.doi.org/10.1111/j.1468-5957.2010.02212.x

Patel, N., 2012, 'Investor relations on the Internet: An empirical study of Indian listed companies', The IUP Journal of Corporate Governance 11(2), 45-59.

Pirchegger, B. \& Wagenhofer, A., 1999, 'Financial information on the Internet: A survey of the homepages of Austrian companies', The European Accounting Review 8(2), 383-395. http://dx.doi.org/10.1080/096381899336113

Venter, J.M.P., 2002, 'A survey of current online reporting practices in South Africa', Meditari 10(1), 209-225. http://dx.doi.org/10.1108/10222529200200011 